\title{
Commentary: Mating Preferences of Selfish Sex Chromosomes
}

\author{
Gilbert Roberts $^{1 *}$ and Marion Petrie ${ }^{2 *}$ \\ ${ }^{1}$ Independent Researcher, Newcastle upon Tyne, United Kingdom, ${ }^{2}$ Biosciences Research Institute, Newcastle University, \\ Newcastle upon Tyne, United Kingdom
}

Keywords: sexual selection, female choice, good genes, Handicap Principle, selfish sex chromosomes

\section{A Commentary on}

Mating Preferences of Selfish Sex Chromosomes

by Muralidhar, P. (2019). Nature 570, 376-379. doi: 10.1038/s41586-019-1271-7

\section{OPEN ACCESS}

Edited by:

Sasha Raoul Xola Dall,

University of Exeter, United Kingdom

Reviewed by:

Olof Leimar,

Stockholm University, Sweden

*Correspondence:

Gillbert Roberts

gillbert.roberts@yahoo.co.uk

Marion Petrie

marion.petrie@ncl.ac.uk

Specialty section:

This article was submitted to Behavioral and Evolutionary Ecology,

a section of the journal

Frontiers in Ecology and Evolution

Received: 08 October 2019

Accepted: 13 November 2019

Published: 29 November 2019

Citation:

Roberts G and Petrie M (2019) Commentary: Mating Preferences of

Selfish Sex Chromosomes.

Front. Ecol. Evol. 7:456.

doi: 10.3389/fevo.2019.00456
Darwin introduced the term sexual selection to explain traits that he could not reconcile with natural selection (Darwin, 1871). His insight was that extravagant, showy traits (typically in males) are selected for because they increase mating success. Current theory holds that females prefer to mate with males bearing these traits because of viability and/or attractiveness benefits to their offspring (Kokko et al., 2002). A recent paper suggests instead that females prefer these "harmful" (viability reducing) male traits due to "selfish sex chromosomes" which bias preference for sexually antagonistic traits, namely those which decrease male fitness relative to that of females (Muralidhar, 2019). We are concerned that the basis of the paper is flawed; that its assumptions are invalid; and that it is inconsistent with the available empirical evidence.

The paper aims to explain why "females prefer males with harmful traits." However, if the male traits did not reduce viability then they could readily be explained by natural selection and there would be no reason to invoke sexual selection. Current theory combines explanations due to Fisher (1930) and to Zahavi and Zahavi (1997) in explaining how showy male traits are adaptations which increase female choice because the bearers provide either direct benefits which increase the female's immediate reproduction or indirect benefits in the form of increased viability and/or attractiveness of offspring. The interesting question is therefore not, why do females choose harmful male traits, but why do sexually selected male traits take the particular forms that they take. Yet the selfish sex chromosome hypothesis fails to address the critical issue of why male traits are showy, as is apparent from the accompanying commentary where Kirkpatrick (2019) says that the selfish sex chromosome theory is unlikely to explain the illustrated phenomenon of bright male coloration. Furthermore, harmful male traits could comprise any of a multitude of traits that negatively impact survival (such as having one leg) and still be consistent with the theory. A particular type of trait calls for a particular type of explanation, but the theory of selfish sex chromosomes does nothing to help us understand the train of the peacock, the dance of the bird of paradise and the song of the nightingale. In contrast, theories of indirect benefits address the form traits should take in order to signal "good genes." The selfish sex chromosome approach therefore sets out to explain a tautologous definition of how male traits are harmful and offers no explanation for their form.

A core aim of Muralidhar (2019) paper is to show how female preferences for harmful traits can invade, something they claim to be a key failure of Fisherian and Handicap-based models. However, 
this is not the case: many models do address the initial evolution of female preferences (see Table 2.1 in Møller, 1994). Furthermore, there is no theoretical reason to separate, as Muralidhar claims, the processes of initial invasion and of subsequent elaboration and maintenance of sexual traits. Many of the models of sexual selection are based on invasion with the much less stringent and more realistic condition that female preference evolves for beneficial male traits. Thus, Muralidhar (2019) model appears to be based on a false premise.

Notwithstanding these issues, if the aim is to explain sexual traits then the model must rest on sound assumptions. The two key assumptions are first that male traits are coded for by sexually antagonistic genes, making traits that are harmful in males beneficial in females, and secondly that female preferences reside on the sex chromosomes. There is insufficient evidence to suggest that either of these are prevalent.

Any theory must be testable, but it is not clear what are the key predictions. If selfish sex chromosomes have played a significant role in sexual selection then it follows that female preference genes will tend to be carried on $\mathrm{W}$ chromosomes. However, as also noted by Kirkpatrick (2019) there is no evidence for this. The empirical evidence given in the supplementary material is weak and does not support the thesis that female preferences will lie on sex chromosomes rather than autosomes. There may be a bias in the strength of sexual selection across chromosomal systems (Reeve and Pfennig, 2003) but, it seems unlikely that chromosomal systems explain why some males have showy traits because there is wide variance within chromosomal systems e.g., many birds are monogamous.

Any theory of sexual selection must be able to explain classic cases. Considering the train of the peacock, Muralidhar's theory proposes that those males carrying the most elaborate trains have the lowest fitness; that the genes causing this harm to the males have sexually antagonistic benefits to the peahens; that female offspring will have relatively high fitness because they inherit "good genes" without the harmful male trait, and that this benefit to female offspring outweighs the low viability of male offspring because the train preference is carried on the $\mathrm{W}$ chromosome. So, if as assumed in the paper, females are choosing males because they bear traits which are "harmful" to them, then the males which females prefer must be those with the traits causing low fitness. However, this is not the case in peacocks because preferred males are more likely to survive predation (Petrie, 1992). Moreover, a meta-analysis shows males with larger ornaments actually have greater survivorship (Jennions et al.,

\section{REFERENCES}

Darwin, C. (1871). The Descent of Man, and Selection in Relation to Sex. London: Murray.

Fisher, R. A. (1930). The Genetical Theory of Natural Selection. Oxford: Oxford University Press.

Jennions, M. D., Moller, A. P., and Petrie, M. (2001). Sexually selected traits and adult survival: a meta-analysis. Q. Rev. Biol. 76, 3-36. doi: 10.1086/ 393743
2001). The premise of Muralidhar (2019) paper is therefore false. Furthermore, peacocks with the most elaborate trains pass on their higher viability to their offspring, and they do this more to their male than their female offspring (Petrie, 1994). This is inconsistent with the claim that female offspring are better off because they inherit viability without harmful male traits (Muralidhar, 2019). Instead, peacocks should not be viewed as having "harmful" traits, since they bear traits that reveal their heritable quality. The accompanying news and views article by Kirkpatrick (2019) also concludes that the theory is unlikely to explain bright avian plumage because color genes are not sexually antagonistic.

A primary aim of the selfish sex chromosomes hypothesis is to explain the initial evolution of female preferences which it says cannot be explained by Handicap and/or Fisherian theories. However, the hypothesis explicitly assumes that these underlie a selfish sex chromosome effect. For example, in the accompanying commentary, Kirkpatrick (2019) assumes that red males have higher mating success, which begs the question of where this comes from if not from the theories of sexual selection that are being challenged; and he says harmful male traits have evolved because only the males that are able to produce the traits are chosen, which sounds like a "good genes" explanation. The selfish sex chromosome theory therefore purports to explain male traits but actually assumes a costly signaling explanation of a link between trait and male quality. If the male trait is signaling high quality, then females will choose males bearing these traits regardless of whether any preference is sex linked. So, Muralidhar (2019) theory cannot help to explain the initial invasion of female choice if its operation actually depends upon the validity of the theories it seeks to replace.

In sum, we are concerned that the selfish sex chromosome theory doesn't add to our understanding of the evolution of sexually selected characters as it cannot explain what we already know about female preferences and male ornaments. It does not give us any reason to think that female preferences are associated with or influenced by selfish maternal genetic elements, as suggested by Muralidhar (2019) and more importantly it risks causing confusion about how sexual selection has shaped traits to increase mating success.

\section{AUTHOR CONTRIBUTIONS}

GR conceived correspondence. GR and MP discussed and contributed to the manuscript. selection continuum. Proc. R. Soc. Lond. Ser. B Biol. Sci. 269, 1331-1340. doi: $10.1098 / \mathrm{rspb} .2002 .2020$

Møller, A. P. (1994). Sexual Selection and the Barn Swallow. Oxford: Oxford University Press.

Muralidhar, P. (2019). Mating preferences of selfish sex chromosomes. Nature 570, 376-379. doi: 10.1038/s41586-019-1271-7 
Petrie, M. (1992). Peacocks with low mating success are more likely to suffer predation. Anim. Behav. 44, 585-586. doi: 10.1016/0003-3472(92) 90072-H

Petrie, M. (1994). Improved growth and survival of offspring of peacocks with more elaborate trains. Nature 371, 598-599. doi: 10.1038/371598a0

Reeve, H. K., and Pfennig, D.W. (2003). Genetic basis for showy males: are some genetic systems especially conducive to sexual selection? Proc. Natl. Acad. Sci. U.S.A. 100, 1089-1094. doi: 10.1073/pnas.0337427100

Zahavi, A., and Zahavi, A. (1997). The Handicap Principle. New York, NY: Oxford University Press.
Conflict of Interest: The authors declare that the research was conducted in the absence of any commercial or financial relationships that could be construed as a potential conflict of interest.

Copyright (C) 2019 Roberts and Petrie. This is an open-access article distributed under the terms of the Creative Commons Attribution License (CC BY). The use, distribution or reproduction in other forums is permitted, provided the original author(s) and the copyright owner(s) are credited and that the original publication in this journal is cited, in accordance with accepted academic practice. No use, distribution or reproduction is permitted which does not comply with these terms. 